\title{
PROBLEMA PENGGANTIAN HUKUM-HUKUM KOLONIAL DENGAN HUKUM-HUKUM NASIONAL SEBAGAI POLITIK HUKUM
}

\author{
Maroni \\ Fakultas Hukum Universitas Lampung \\ E-mail: maroni@unila.ac.id dan maroniunila@gmail.com
}

\begin{abstract}
Replacement of colonial law was committed by Indonesia since the first, but fact there are still lot of colonial law have a status as positive law. The problems, what is the problematic causing factors of replacement colonial law with national law and how the politics of law response its problematics? The results of the study describe that the causing factors consist of (a) the heterogeneity of Indonesian nation, (b) embrace the principle of unification and codification; (c) differences in views on human rights. While, the politics of law formed as guidance for the colonial laws which are difficult to change such the law that relating to social life, cultural and spiritual. In other case, the field of "neutral" law such contract law and in the field of commercial law changing by renewal or creation the law.
\end{abstract}

Keywords: Problems, colonial, national, politics of law.

\begin{abstract}
Abstrak
Penggantian hukum kolonial sudah lama dilakukan oleh bangsa Indonesia, namun kenyataannya saat ini masih banyak hukum kolonial berstatus sebagai hukum positif. permasalahannya apakah faktor penyebab problematik penggantian hukum kolonial dengan hukum nasional dan bagaimanakah politik hukum sehubungan adanya problematik tersebut?. Hasil kajian, faktor penyebabnya (a) heterogenitas bangsa Indonesia; (b) dianutnya prinsip unifikasi dan kodifikasi; (c) perbedaan pandangan terhadap HAM. Sedangkan politik hukumnya berbentuk pembinaan bagi hukum kolonial yang sukar diganti seperti bidang hukum yang berkaitan kehidupan kemasyarakatan, budaya dan spiritual. Sedangkan bidang hukum "netral" seperti hukum perikatan dan hukum dalam bidang perdagangan dilakukan pergantian melalui dimensi pembaharuan atau penciptaan hukum.
\end{abstract}

Kata Kunci: Problema, kolonial, nasional, politik hukum

\section{Pendahuluan}

Penggantian hukum-hukum kolonial (peninggalan Belanda) dengan hukum-hukum nasional (reformasi hukum) dalam rangka membangun sistem hukum nasional yang berorientasi pada falsafah hukum Pancasila saat ini dirasakan sangat mendesak, hal ini mengingat walau pun bangsa Indonesia telah lebih dari 60 tahun merdeka namun sistem hukumnya masih sangat kental diwarnai oleh nilai-nilai sistem hukum kolonial (kultur liberal dan individual). Padahal sistem hukum suatu bangsa tidak dapat dilepaskan dari konteks manusianya karena hukum ada dan diperuntukkan untuk kehidupan manusia. ${ }^{1}$

Bandingkn dengan pendapat Shidarta mengenai sifat sistem hukum pada Shidarta, "Penalaran Hukum Dalam Sudut Pandang Keluarga Sistem Hukum dan Penstudi
Oleh sebab itu norma hukum selalu mengandung kultur hukum masyarakat yang membentuknya. Hal ini mengingat bahwa hukum itu bukan sesuatu yang jatuh dari langit, melainkan berakar pada suatu komunitas sosial-kultural tertentu. Komunitas tersebut dapat diibaratkan sebagai ibu yang menyusui anaknya. Dalam hal ini, masyarakat yang menyusui hukumnya dengan sekalian nilai, sejarah dan tradisinya.

UUD 1945 merupakan sumber hukum yang paling mendasar, hukum tertinggi yang mengandung nilai, asas dan norma yang harus di patuhi, dijunjung tinggi, dan dilaksanakan dalam setiap pengambilan keputusan dan/atau

Hukum", J urnal IImiah IImu Hukum "Era Hukum" No. 1 Tahun 11 September 2003. hlm. 20. 
kebijakan hukum baik oleh pemerintah, legislatif, dan badan-badan yudisial, serta rakyat pada umumnya. Oleh karena itu di dalam sistem hukum nasional yang hendak dibangun dan pelaksanaannya dalam bentuk politik hukum nasional $^{2}$, harus tetap dijaga dan dipertahankan semangat dan nilai-nilai fundamental yang terkandung dalam dasar falsafah negara Pancasila yang termuat dalam Pembukaan UUD 1945 dan seluruh pasal-pasalnya sebagai landasan falsafah dan konstitusional negara. ${ }^{3}$

Adapun karakteristik hukum nasional Indonesia menurut Pancasila, adalah: Sila Ketuhanan YME, memberikan inspirasi bahwa Sistem Hukum Nasional harus bernapaskan moral religius yang beradab, bukan berdasarkan hukum agama dari suatu agama tertentu; Sila Kemanusiaan yang Adil dan Beradab, memberikan inspirasi bahwa Sistem Hukum Nasional harus mengindahkan hak-hak asasi manusia; Sila Persatuan Indonesia, akan memberikan inspirasi bahwa Sistem Hukum Nasional harus mencerminkan jiwa dan rasa keadilan bagi seluruh rakyat Indonesia; Sila Kerakyatan yang dipimpin oleh hikmat kebijaksanaan dalam permusyawaratan/perwakilan, akan memberikan inspirasi bahwa Sistem Hukum Nasional harus dirumuskan dengan mengikutsertakan atau memperhatikan aspirasi dan rasa keadilan seluruh rakyat Indonesa; Sila keadilan sosial bagi seluruh rakyat Indonesia, akan memberikan inspirasi bahwa Sistem Hukum Nasional tidak mengenal konsep keadilan yang semata-mata berlingkup individu, melainkan juga keadilan yang menu-ju terselenggaranya kesejahteraan bersama. ${ }^{4} \mathrm{Ka}$ rakteristik tersebut merupakan pencerminan

2 Endang Sutrisno, "Mengukuhkan Paradigma Hukum di Era Orde Reformasi", Jurnal IImiah FH Unswagati Cirebon, Edisi: 01/J uni/ 2005, hlm. 34.

3 T. Gayus Lumbun, "Budaya Hukum Mempengaruhi Pelestarian Fungsi Lingkungan", J urnal IImiah IImu Hukum "Era Hukum" No. 1 Tahun 11 September 2003, hlm. 23. Bandingkan dengan Mahmutarom yang berpendapat kurangnya kesadaran akan muatan nilai-nilai Pancasila sebagai satu kesatuan/sistem nilai dalam peraturan perundang-undangan. Mahmutarom, "Pembangunan Hukum Nasional Dalam Konteks Global", Majalah MasalahMasalah Hu-kum FH UNDIP Vol 35 No 1 Januari-Maret 2006, hlm. 84.

4 Lihat dalam M. Ali Mansyur, "Pancasila Sebagai Dasar Pengembangan IImu Hukum Indonesia", J urnal Hukum Vol. XV No. 1 J uni 2005 FH Unissula, hlm. 13. dari asas-asas hukum yang terkandung dalam Pancasila meliputi: asas religius; asas kemanusiaan; dan asas kemasyarakatan. ${ }^{5}$

Walaupun usaha menciptakan hukum nasional telah lama dicanangkan, namun usaha tersebut belum dapat berjalan sebagaimana yang diharapkan. Hal ini terlihat masih banyaknya hukum-hukum peninggalan kolonial yang sampai saat ini masih berlaku seperti Kitab Undang-Undang Hukum Pidana, Kitab UndangUndang Hukum Perdata, Kitab Undang-Undang Hukum Dagang, Het Herzine Inlands Reglemen (HIR/RBG). Bahkan berdasarkan inventarisasi yang dilakukan Badan Pembinaan Hukum Nasional, terdapat sekitar 380 (tiga ratus delapan puluh) peraturan dari masa kolonial yang masih berlaku. Namun sangat disayangkan, politik hukum bangsa Indonesia saat ini tidak mendukung ke arah penggantian hukum-hukum kolonial, ini terlihat dari sebanyak 71 (tujuh puluh satu) Rencana Undang-Undang (RUU) dalam Program Legislasi Nasional (Prolegnas) 2011, ${ }^{6}$ hanya ada satu RUU yang merubah hukum kolonial yaitu RUU KUHP itupun merupakan program legislasi sebelumnya yang belum terlaksana. Kondisi tersebut diakui oleh pakar hukum tata negara Universitas Indonesia Satya Arinanto, bahwa, "Memang ada beberapa peraturan yang sudah di ubah, tetapi pada praktiknya masih banyak peraturan kolonial. Salah satu tantangan kita adalah memerdekakan hukum dari produk-produk hukum asing,". Selanjutnya ia mengakui bahwa pemerintah lambat mereformasi sistem hukumnya. Salah satu penyebab kelambatan tersebut, menurut Satya, adalah kesulitan yang tinggi. Hal itu berlaku untuk beberapa produk hukum, seperti Kitab Undang-undang Hukum Pidana, Kitab Undang-undang Hukum Perdata, Kitab Hukum Dagang. Meski demikian, ia melihat pemerintah memiliki visi mengubah produk kolonial tersebut. Ini tercantum dalam Peraturan Peme-

\footnotetext{
5 Lihat dan bandingkan dengan pendapat Maleha Soemarsono mengenai sistem hukum Pancasila dalam Maleha Soemarsono, "Negara Hukum Indonesia Ditinjau Dari Sudut Teori Tujuan Negara", Jurnal Hukum \& Pembangunan Tahun-37 No. 2 April-J uni 2007, hlm. 318-319.

6 http:// mediaindonesia.com. diunduh 10 J uni 2011
} 
rintah Nomor 7 Tahun 2005 tentang Rencana Pembangunan J angka Menengah. ${ }^{7}$

Berdasarkan latarbelakang di atas, permasalahan dalam tulisan ini adalah apakah faktor-faktor penyebab adanya problematik penggantian hukum kolonial dengan hukum nasional, dan bagaimanakah politik hukum sehubungan adanya problematik penggantian hukum kolonial dengan hukum nasional?

\section{Pembahasan}

Merujuk pada berbagai paradigma tentang pengertian hukum, maka yang dimaksud hukum kolonial dan hukum nasional dalam tulisan ini adalah hukum positif yang berbentuk peraturan perundangan yang dibuat oleh pemerintah kolonial dan peraturan perundang-undangan yang dibuat oleh Negara Kesatuan Republik Indonesia. Sedangkan pengertian politik hukum ialah kebijaksanaan dari negara dengan perantaraan badan-badan yang berwenang untuk menetapkan peraturan-peraturan yang dikehendaki, yang diperkirakan bisa digunakan untuk mengekspresikan apa yang terkandung dalam masyarakat dan untuk mencapai apa yang dicita-citakan. Pengertian di atas sejalan dengan pandangan Moh. Mahfud MD bahwa politik hukum adalah legal policy yang akan atau telah dilaksanakan secara nasional oleh Pemerintah Indonesia yang meliputi: pertama, pembangunan hukum yang berintikan pembuatan dan pembaruan terhadap materi-materi hukum agar dapat sesuai dengan kebutuhan; kedua, pelaksanaan ketentuan hukum yang telah ada termasuk penegasan fungsi lembaga dan pembinaan para penegak hukum. Dari pengertian tersebut terlihat politik hukum mencakup proses pembuatan dan pelaksanaan hukum yang dapat menun-jukkan sifat dan ke arah mana hukum akan dibangun dan ditegakkan ${ }^{8}$.

Usaha bangsa Indonesia untuk menciptakan hukum nasional sebagai pengganti hukum-

http:// www2. kompas.com/ diunduh 17 J anuari 2010.

Bandingkan pendapat Gayus T. Lumbun mengenai politik hukum dalam Gayus T. Lumbun, Politik Hukum Bidang Peradilan di Indonesia, Majalah Hukum Nasional BPHN Depkum-ham RI. No. 1 Tahun 2008, hlm. 205, Lihat juga Umar Ma'ruf, "Politik Hukum Hak Menguasai oleh Negara Terhadap Tanah", J urnal IImu Hukum Vol. XVI. No. 3 September 2006 FH Unissula, hIm. 374. hukum kolonial telah di mulai sejak Indonesia diproklamasikan pada tanggal 17 Agustus 1945 sebagai negara merdeka dan UUD 1945 sebagai hukum dasarnya. Proklamasi kemerdekaan menuntut pembaharuan atau penggantian atas hukum-hukum peninggalan zaman penjajahan Jepang dan Belanda, sebab jika di lihat dari sudut tata hukum maka proklamasi kemerdekaan merupakan tindakan perombakan secara total. Proklamasi kemerdekaan telah membawa Indonesia pada idealita dan realita hukum yang lain dari sebelumnya. Proklamasi kemerdekaan telah mengubah tradisi masyarakat dari keadaan terjajah menjadi masyarakat bebas (merdeka). Tujuan hukum pun harus berubah secara berbalikan dari tujuan mempertahankan dan melestarikan penjajahan menjadi mengisi kemerdekaan dengan etos yang juga berubah dari penjajahan menjadi kebangsaan. Usaha tersebut lebih dikonkritkan lagi pada tahun 1963 yaitu pada waktu diadakannya Seminar Hukum Nasional Pertama, dengan pokok-pokok pikiran tentang politik pembinaan hukum Indonesia yaitu hukum Indonesia dibina sesuai dengan tingkat-tingkat revolusi, pembinaan hukum diarahkan kepada unifikasi hukum dalam segala bidang dengan memperatikan ciri-ciri khas dan tingkat perkembangan masyarakat daerah tersebut. Namun usaha tersebut belum sepenuhnya terwujud, hal ini ditandai masih banyaknya produk hukum peninggalan kolonial yang masih berlaku sebagai hukum positif di Indonesia sampai saat ini.

\section{Faktor Penyebab Adanya Problematik Peng- gantian Hukum Kolonial dengan Hukum Nasio- nal}

Ada beberapa faktor penyebab timbulnya problematika penggantian hukum kolonial dengan hukum nasional. Bagian di bawah ini akan menjelaskan faktor-faktor penyebab tersebut. Pertama, heteroginitas bangsa Indonesia. melakukan pergantian hukum kolonial menjadi hukum nasional berdasarkan Pancasila dan UUD 1945 tidak dapat dilakukan seperti membalikkan telapak tangan, melainkan harus memperhatikan karakteristik Indonesia. Indonesia adalah negara kepulauan terbesar di dunia yang 
mempunyai 17.508 pulau. Indonesia terbentang antara 6 derajat garis lintang utara sampai 11 derajat garis lintang selatan, dan dari 97 derajat sampai 141 derajat garis bujur timur serta terletak antara dua benua yaitu benua Asia dan Australia/Oceania. Wilayah Indonesia terbentang sepanjang 3.977 mil antara Samudra Hindia dan Samudra Pasifik. Apabila perairan antara pulau-pulau itu digabungkan, maka luas Indonesia menjadi 19 juta mil persegi, Lima pulau besar di Indonesia adalah: Sumatera dengan luas $473.606 \mathrm{~km}$ persegi, Jawa dengan luas $132.107 \mathrm{~km}$ persegi, Kalimantan (pulau terbesar ketiga di dunia) dengan luas $539.460 \mathrm{~km}$ persegi, Sulawesi dengan luas $189.216 \mathrm{~km}$ persegi, dan Papua dengan luas $421.981 \mathrm{~km}$ persegi.

Penduduk Indonesia dapat dibagi secara garis besar dalam dua kelompok. Di bagian barat Indonesia penduduknya kebanyakan adalah suku Melayu sementara di timur adalah suku Papua, yang mempunyai akar di kepulauan Melanesia. Banyak penduduk Indonesia yang menyatakan dirinya sebagai bagian dari kelompok suku yang lebih spesifik, yang dibagi menurut bahasa dan asal daerah, misalnya J awa, Sunda atau Batak. Islam adalah agama mayoritas yang dipeluk oleh sekitar 85,2\% penduduk Indonesia, yang menjadikan Indonesia negara dengan penduduk muslim terbanyak di dunia. Sisanya beragama Protestan (8,9\%); Katolik (3\%); Hindu $(1,8 \%)$; Budha $(0,8 \%)$; dan lain-lain $(0,3 \%)$. Indonesia terdiri dari berbagai suku bangsa, agama serta kepercayaan yang berbeda. Ada Batak, Karo, Minangkabau, Melayu di Sumatera dan sebagainya. ${ }^{9}$

Karakteristik di atas menimbulkan persoalan tersendiri bagi bangsa Indonesia dalam melakukan pergantian terhadap hukum kolonial Belanda yang di bangun berlandaskan prinsipprinsip individualisasi dan liberalisasi sebagaimana ciri hukum Eropa Kontinental (civil law system) pada umumnya. Kondisi tersebut bertolak belakang dengan karakteristik hukum bangsa Indonesia berdasarkan Pancasila dan UUD 1945 (Bhineka Tunggal Ika) yang bersifat komu-

9 http:// www. Indonesia.go.id/ diunduh tgl. 1 Maret 2011 nal dan kekeluargaan. ${ }^{10}$ Adanya perbedaan karakteristik tersebut yang menimbulkan problematik untuk menggantikan hukum kolonial khususnya bidang hukum yang berkaitan dengan kehi-dupan kemasyarakatan, budaya dan spiritual. ${ }^{11}$ Sedangkan bidang hukum "netral" seperti hukum perikatan dan hukum dalam bidang perdagangan relatif tidak bermasalah dikarenakan tidak langsung berkaitan dengan karakteristik bangsa Indonesia ${ }^{12}$. Alasan tersebut sesuai dengan pendapat Satjipto Rahardjo ${ }^{13}$ bahwa Indonesia benar-benar merupakan masyarakat majemuk nomor wahid di dunia. Secara topografis Indonesia berupa negara kepulauan yang terdiri dari sejumlah pulau-pulau besar dan ribuan pulau-pulau kecil, tetapi lebih daripada itu berupa komunitas-komunitas manusia dengan ratusan warna lokal dan etnis. Ini jauh berbeda dengan J epang, yang juga berupa negara kepulauan, tetapi dengan entitas yang tunggal dan kokoh. Hukum yang menghadapi realitas tunggal harus mencari, menemukan dan membangun cara-cara serta teknik tersendiri untuk bisa menjadi satu-satunya institut penentu dan penjaga ketertiban dalam ruang kehidupan yang supra majemuk itu. Kehidupan yang penuh dengan homogenitas ini bisa dilayani oleh model seragam, mutlak dan sentralistis seperti model hukum kolonial, namun sebaliknya bagi kehidupan yang bersifat heterogenitas tidaklah demikian. ${ }^{14}$

10 Lihat mengenai hukum Indonesia Asli pada Ahmadi Hasan, "Adat Badamai Sebagai Penyelesaian Sengketa Dalam Sistem Hukum Nasional", J urnal Konstitusi PKK Fakultas Syariah IAIN Antasari, Vol. I No 1 Nov 2008, hlm. 43.

11 Bandingkan pendapat Romli Atmasasmita, "Tiga Paradigma Hukum Dalam Pembangunan Nasional", Majalah Hukum Nasional BPHN Depkumham No. 2 Tahun 2011, hlm. 194.

12 Bandingkan dengan pendapat Astim Riyanto mengenai ciri-ciri tradisi hukum pada masing-masing sistem. Astim Riyanto, "Sistem Hukum Negara-Negara Asia Tenggara", Jurnal Hukum \& Pem-bangunan Tahun-37 No. 2 April-J uni 2007, hlm. 265. Lihat juga Tri Sulistiyono, "Pluralisme Hukum; Menggapai Hukum Adat Gaya Baru yang Berperspektif Keadilan Gen-der", J urnal Konstitusi Vol. I, No. 1. Nopember 2008, PKK UNNES, hlm. 83.

13 Rahardjo, Satjipto. 2007. Biarkan Hukum Mengalir: Catatan Kritis tentang Pergulatan Manusia dan Hukum. J akarta: Penerbit Buku Kompas, hlm. 30.

14 Bandingkan pendapat Zudan Arif Fakrulloh mengenai heterogenitas masyarakat Indonesia dalam kaitannya dengan hukum pada Zudan Arif Fakrulloh, "Model Hukum Yang Humanis Partisipa-toris: Ide Dasar dan Teori- 
Kedua, faktor dianutnya prinsip unifikasi dan kodifikasi dalam sistem hukum nasional. Di anutnya prinsip unifikasi dan kodifikasi berdasarkan Ketetapan MPR No. II/ MPR/ 1988 tentang Garis-Garis Besar Haluan Negara (GBHN), yaitu memberlakukan seluruh wilayah Indonesia dengan hukum yang sama dalam sistem hukum nasional, walaupun sama dengan prinsip yang dianut hukum kolonial, namun dipandang sebagai salah satu faktor problem penggantian hukum kolonial menjadi hukum nasional. Hal ini mengingat sifat 'Bhinneka Tunggal Ika' negara kita, tidak akan mungkin menghendaki dilaksanakannya apa yang disebut sebagai 'unifikasi hukum nasional'. Tidak ada negara yang begitu hete-rogen seperti Indonesia yang akan mampu melaksanakan unifikasi hukum secara menyeluruh. Bahkan tidak juga Jerman yang begitu homogen kulturnya, mampu melaksanakannya. Mungkin hanya negara yang sangat homogen seperti J epang atau Korea yang cocok untuk melaksanakan hukum yang unified. Unifikasi hukum Indonesia nampaknya hanya akan dapat dilaksanakan untuk bidang-bidang hukum yang oleh para pakar hukum kita disebut 'netral', misalnya hukum perjanjian, perseoran dan hukum perniagaan pada umumnya merupakan bidang-bidang hukum yang lebih tepat bagi usaha pembaharuan, sedangkan bidang-bidang hukum yang erat hubungannya dengan kehidupan budaya dan spirituil masyarakat seperti hukum kekeluargaan, perkawinan dan perceraian serta waris akan mengalami kesulitan dalam melakukan pembaharuan hukum. ${ }^{15}$ Mengingat tradisitradisi lokal pun harus juga dihormati dalam kerangka 'Bhinneka Tunggal Ika', nampaknya bidang-bidang hukum seperti hukum pidana dan hukum perdata sulit untuk diunifikasikan, apalagi hukum keluarga dan hukum waris. Dalam kerangka ini nampaknya perlu kita pikirkan dengan kepala dingin, apakah sejumlah prinsip dalam 'intergential recht' warisan Belanda yang nota bene menghormati existensi dari ke-

sasinya dengan Latar Sosial Indonesia", J urnal IImiah Hukum Legality Vol. 9. No. 2. September 2001-J anuari 2002, UMM Malang, hlm. 182.

15 Mochtar Kusumaatmadja, 1986, Pembinaan Hukum dalam Rangka Pembangunan Nasional. Bandung: Binacipta, hlm. 6.
19 rumpun budaya Indonesia serta aneka agama itu bukannya malahan perlu dipertahankan. ${ }^{16}$

Begitu juga dianutnya prinsip kodifikasi dalam sistem hukum nasional berdasarkan Ketetapan MPR No. II/MPR/ 1988 tentang GarisGaris Besar Haluan Negara (GBHN), yang meniru prinsip yang dianut hukum kolonial, dipandang sebagai penyebab sulitnya penggantian hukum kolonial menjadi hukum nasional dewasa ini. Prinsip kodifikasi menuntut berbagai peristiwa dan perbuatan hukum diatur dan dibukukan dalam satu sistem perundang-undangan yang sama. Sebagai contoh Kitab Undang-Undang Hukum Pidana (KUHP), Kitab Undang-Undang Hukum Perdata (KUHPdt) dan lain sebagainya. Dalam kaitannya dengan hukum pidana, suatu kodifikasi antara satu asas dengan asas yang lain hendaknya ditempatkan pada suatu tatanan sistematik yang sedemikian rupa sehingga jelas hubungannya dan jelas apa yang menjadi dasar norma-norma yang telah ditentukan sebagai perbuatan yang melanggar dan diancam dengan pidana. Kebijakan ini akan mengalami hambatan manakala peristiwa dan perbuatan hukum yang akan dikodifikasikan tersebut karena sifat dan perkembangannya relatif cepat berubah sehingga apabila dikodifikasikan akan mengganggu sistem kodifikasi itu sendiri. Sebagai contoh dalam bidang hukum pidana kesukaran penerapan prinsip kodifikasi berkaitan dengan cepatnya berubah modus operandi suatu kejahatan dan banyaknya model kejahatan-kejahatan baru yang bersifat kontemporer yang tidak bisa diatasi dengan menggunakan sistem kodifikasi me-lainkan diatur dalam undang-undang bersifat parsial dan khusus (lex specialis), sehingga apabila terjadi perubahan mudah untuk melakukan penyesuaian dengan merubah undang-undang dimaksud tanpa merubah sistem kodifikasi. ${ }^{17}$

16 Budiono Kusumohamidjojo, "Politik Hukum dan Pembangunan Hukum Nasional Dalam PJ PT II", Pro Justitia Majalah Hukum Unpar Bandung, 1993, hlm. 77.

17 Bandingkan pendapat Mudzakkir mengenai kebijakan pengaturan hukum pidana di luar KUHP pada Mudzakkir, "Kebijakan Kodifikasi (Total) Hukum Pidana Melalui RUU KUHP dan AntisipasiTerhadap Problem Perumusan Hukum Pidana dan Penegakan Hukum Pidana di Masa Datang", Majalah Hukum Nasional BPHN Depkumham No. 1 Tahun 2011, hlm. 21 
Selain itu sukar untuk disangkal bahwa mengingat pada akhirnya kodifikasi merupakan produk dari proses legislasi. Padahal kita menyaksikan bahwa proses legislasi kita dalam beberapa dasawarsa terakhir adalah lebih lambat dari hampir semua proses di berbagai sektor kehidupan lainnya dalam masyarakat. Kita hidup dalam zaman yang ditandai oleh proses sosial yang kecepatannya belum pernah disaksikan dalam sejarah dunia, dan pada saat yang sama kita dilayani oleh mesin birokrasi yang gemuk, rumit, dan sangat lamban. Mungkin itu sebabnya, mengapa Charles Himawan, ketika dilan-tik sebagai profesor pada Fakultas hukum Universitas Indonesia bahkan tidak ragu-ragu untuk menegaskan dalam pidatonya, bahwa 'hukum di Indonesia sedang dalam keadaan tidur'. Memang lalu menjadi sukar untuk membayangkan, bahwa dengan hukum yang 'tidur' perjuangan besar untuk membangun negara akan berakhir dalam suatu kesuksesan. Itulah sebabnya timbul keraguan atas pendapat Roscoe Pound bahwa "law is a tool for social engineering". Dia memang mendapatkan banyak pengikut di Indonesia, tetapi dalam kenyataannya, kita masih jauh dari apa yang dipercayai oleh Roscoe Pound sebagai kebenaran. Sukar mempercayai bahwa hukum dapat digunakan sebagai alat untuk mere-kayasa masyarakat, apabila hukum itu 'tidur'. Kodifikasi diperlukan dalam lingkup material tertentu dan jangkauan geografis yang terbatas, dan itulah sebabnya mengapa negara-negara yang secara tradisional menerapkan common law pada akhirnya juga memberlakukan aneka 'bills' dan 'laws'. ${ }^{18}$

Konteks 'Bhinneka Tunggal Ika', menyatakan banyak kalangan mengakui penerapan prinsip kodifikasi secara nasional hanya pada bidang-bidang hukum yang 'netral' sifatnya, yang terutama menyangkut kegiatan perdagangan. Selebihnya harus diserahkan kepada yurisprudensi dan bahkan juga peraturan daerah. Contoh besar dari kodifikasi yang 'seenaknya' adalah Undang-Undang Nomor 14 tahun 1992, yang menentukan sanksi:'satu juta rupiah atau

18 Budiono Kusumohamidjojo, op. cit. hlm. 78. satu bulan kurungan' yang mencerminkan 'cara berhitung orang di Jakarta' tanpa mau tahu situasi di daerah-daerah. ${ }^{19}$

Upaya agar peraturan perundangan Indonesia tidak menimbulkan efek negatif dalam penegakkannya, maka sejak pembentukannya harus memperhatikan atau mengakomodasi nilai-nilai kebhinekaan sebagai perwujudan kepentingan hukum masyarakat tempat dimana peraturan perundang-undangan tersebut akan diberlakukan. Penerapan suatu sistem hukum yang tidak berasal atau ditumbuhkan dari kandungan masyarakatnya merupakan masalah, khususnya di negara-negara yang sedang berubah karena terjadi ketidakcocokan antara nilai-nilai yang menjadi pendukung sistem hukum dari negara lain dengan nilai-nilai yang dihayati oleh anggota masyarakat itu sendiri. ${ }^{20} \mathrm{Da}$ lam kaitannya dengan hukum pidana, maka konstruksi bangunan hukum pidana Indonesia harus dibangun di atas paradigma hukum untuk tujuan kemanusiaan, artinya "hukum bukanlah untuk hukum, tetapi hukum adalah untuk tujuan kemanusiaan". Dipandu paradigma hukum untuk tujuan kemanusiaan tersebut, maka keberadaan perundang-undangan negara tidak lagi dipandang sebagai kitab suci yang mengandung skema-skema hukum bersifat pasti dan final, melainkan sekedar pedoman bagi penguasa negara untuk bertindak dalam kasus-kasus tertentu demi mempertahankan nilai kemanusian, sehingga pedoman tersebut dimungkinkan untuk diterobos, karena pertanggungjawaban para penegak hukum bukanlah pada undang-undang, melainkan pada tujuan perlindungan kemanusiaan.

Ketiga, perbedaan Pandangan terhadap HAM. Proses globalisasi tidak hanya melanda kehidupan ekonomi tetapi telah melanda kehidupan yang lain seperti politik, sosial, budaya, hankam, iptek, pendidikan dan hukum. Globalisasi politik antara lain berupa gerakan tentang HAM, demokrasi, transparansi dan sebagainya.

19 Ibid.

20 Lihat dan bandingkan mengenai kondisi nilai, prinsip dan norma hukum rakyat dalam Didik Sukriono, "Politik Hukum Pemerintahan Desa di Indonesia", Jurnal Konstitusi Vol.I, No. 1, September 2008, PKK Universitas Kanjuruhan Malang, hlm. 16. 
Globalisasi semakin memperkuat pemikiranpemikiran untuk mengoperasionalkan nilai-nilai dasar HAM yang bersifat "universal, indivisible and interdependent and interrelated". Bahkan seringkali ditegaskan agar masyarakat internasional memperlakukan HAM secara global "in a fair and equal manner, on the same footing and with the same emphasis" ${ }^{21}$. Di dalam Vieena Declaration and Programme of Action (J une 1993) butir E. 83 yang mengatur tentang "Implementation and monitoring methods" ditegaskan bahwa pemerintah-pemerintah hendaknya menggabungkan (incorporate) standar-standar yang terdapat pada instrumen-instrumen HAM internasional ke dalam hukum nasional (domestic legismation) dan memperkuat pelbagai struktur, lembaga nasional dan organ-organ dalam masyarakat yang memainkan peran di dalam mem-promosikan dan melindungi HAM. ${ }^{22}$

Penerapan prinsip-prinsip HAM internasional yang bersifat individual dan liberal sebagaimana yang dianut hukum-hukum kolonial ke dalam sistem hukum nasional sebagaimana diuraikan di atas tentunya harus dianalisa secara akurat, sebab secara tradisional sekalipun sudah mempertimbangkan dunia yang semakin "borderless", ideologi dan konstitusi suatu bangsa pada dasarnya sekaligus merupakan semacam "integrated bill of right" negara tersebut. ${ }^{23}$ Ini mengingat konsitusi yang merupakan perwujudan ideologi bangsa, secara hati-hati telah menggambarkan dan sekaligus membatasi kekuasaan peme-rintah dan tidak sekedar memuat pelbagai rumusan bahasa yang indahindah, yang peru-musan norma-norma dasarnya sangat dipengaruhi oleh sistem nilai yang ber-

21 Lihat Abu Rokhmad mengenai promosi dan penegakan HAM sebagai salah satu elemen utama supremasi hukum, dan supremasi hukum. Abu Rokhmad, "HAM dan De-mokrasi di Era Globalisasi Menuju Promosi dan Perlindungan HAM Generasi Kedua", J urnal Hukum Vol. XV. No. 3 Desember 2005 FH Unissula. hlm. 497

22 Lihat dan bandingkan dengan Dadan Wildan. "Nasionalisme dan Jati Diri Bangsa di Era Globalisasi", J urnal Sekretariat Negara RI Negarawan, No. 08 Mei 2008, hlm. 146,

23 Bandingkan pendapat Noor Aziz Said mengenai falsafah liberalisme yang dianut sistem hukum nasional. Noor Aziz Said, "Aspek-Aspek Sosiologik Sistem Hukum Nasional (Tinjauan Kritis Terhadap Kasus Bank Century)", J urnal Dinamika Hukum, Vol. 10 No. 3 September 2010, hlm. 225, laku pada bangsa tersebut. Inilah yang menyebabkan munculnya dorongan negara-negara berkembang termasuk Indonesia untuk memperjuangkan prinsip relativisme kultural dalam penerapan HAM, dengan menekankan betapa pentingnya "national and regional particularities and varios historical, cultural and religious backrounds" (Vienna Declaration and Programme of Actions 1993 I.5.). Demikian pula Deklarasi Kuala Lumpur tentang HAM yang dihasilkan AIPO (Asean Inter-Parliamentary Organization) 1993, yang menegaskan betapa pentingnya "inherent historical experiences, and changing economic, social, political and cultural realities and value system" ${ }^{24}$.

Bagi Indonesia pandangan terhadap HAM tidak terlepas dari pandangan Pancasila terhadap hakikat manusia yang menurut Notonego$\mathrm{ro}^{25}$ yaitu kesatuan dari bagian-bagian susunan kodrat terdiri dari jiwa dan raga, sifat kodrat (makhluk individu dan sosial), dan kedudukan kodrat (makhluk berdiri sendiri dan makhluk Tuhan). Oleh sebab itu aliran yang diajarkan oleh filsafat Pancasila mengenai hakikat manusia disebut "mono-pluralisme" atau "sarwa tunggal", sehingga manusia adalah makhluk "mono-dualistik" atau makhluk "mono-pluralistik". Berdasar-kan pengertian ini, maka terhadap pandangan yang menyatakan bahwa perkembangan manusia bertolak dari kebebasan manusia sebagai kebebasan individual sebagaimana yang dianut oleh negara-negara barat bertentangan dengan aj aran filsafat Pancasila.

Filsafat Pancasila mengajarkan bahwa manusia hanya dapat berkembang secara utuh di dalam lingkungan sosial, karena untuk memperjuangkan kepentingannya manusia selalu memerlukan bantuan orang lain. Oleh sebab itu kebebasan manusia dikembangkan dalam kehidupan sosial melalui keselarasan, keserasian, dan keseimbangan antara hak dan kewajibannya. Pancasila mengajarkan bahwa manusia

24 Bandingkan dengan pendapat Franz Magnis Soseno, mengenai konsep HAM yang berdimensi ganda pada Mulyanto, "Potret Nilai Universal Versus Nilai Partikular Hak Asasi Manusia (HAM) Dalam Bingkai Konstitusi di Indonesia", J urnal Konstitusi P3KHAM LPPM Universitas Sebelas Ma-ret Vol. I, No. 1, Agustus 2008, hlm. 44.

25 SS, Soehardjo. 1993. Filsafat Hukum, Bahan Kuliah Program Magister Hukum Undip Semarang, hlm. 10. 
adalah makhluk Tuhan yang otonom, artinya mengakui bahwa manusia memang bebas, merdeka akan tetapi kebebasan tersebut bukannya tak terbatas. Faktor-faktor yang membatasinya adalah diri sendiri, orang lain atau masyarakat, alam lingkungan, dan juga Tuhannya. Selain itu filsafat Pancasila menempatkan manusia sebagai makhluk berbudaya memiliki potensi pikir, rasa, karsa, dan cipta. Oleh karena itu sistem hukum nasional yang berorientasi Pancasila selain memperhatikan hak-hak asasi manusia (HAM), juga harus memperhatikan kewajiban asasi manusia (KAM). Sistem hukum kolonial yang hanya memperhatikan HAM dan tidak mengenal KAM dipandang sebagai penyebab adanya problematik pergantian hukum kolonial dengan hukum nasional.

\section{Politik Hukum dalam Mengatasi Problematik Penggantian Hukum Kolonial dengan Hukum Nasional}

Salah satu pilar Grand Design Sistem dan Politik Hukum Nasional adalah prinsip bahwa hukum mengabdi pada kepentingan bangsa untuk memajukan negara dan menjadi pilar demokrasi dan tercapainya kesejahteraan rakyat. Oleh karena itu produk hukum yang dihasilkan adalah hukum yang konsisten dengan falsafah Negara, mengalir dari landa-san konstitusi UUD 1945 dan secara sosiologis menjadi sarana untuk tercapainya keadilan dan ketertiban masyarakat.

Persoalan mendasar, terkait grand design Pembangunan Sistem dan Politik Hukum Nasional, adalah bagaimana membuat struktur sistem hukum (legal system) yang kondusif bagi keberagaman subsistem, keberagaman substansi, pengembangan bidang-bidang hukum yang dibutuhkan masyarakat, juga kondusif bagi terciptanya kesadaran hukum masyarakat dan kebebasan untuk melaksanakan hak-hak dan kewajiban-kewajiban sesuai dengan aturan yang berlaku. ${ }^{26}$ Tegasnya, harus ada kebijakan hu-

26 Bandingkan pendapat Mutiara Hikmah, yang menyatakan bahwa dalam rangka mendorong terwuj udnya hukum nasional maupun penerapan hukum, maka memupuk pertumbuhan kesadaran hukum serta membinanya, para penegak hukum mempunyai peran yang amat besar. Mutiara Hikmah, "Aspek Penegakan Hukum Pada kum (legal policy) yang jelas untuk menciptakan kondisi di atas. ${ }^{27}$ Berkaitan dengan ini, sistem hukum dan konstitusi juga harus dapat merespon dinamika dan tantangan zaman dan kehidupan bernegara yang bertumpu pada konsensus reformasi. Oleh karena itu produk hukum yang dihasilkan harus mencerminkan aspek filosofis, yuridis, sosiologis dan historis, sehingga kehidupan bangsa dan negara harus berkesinambungan. ${ }^{28}$

Berkaitan dengan hal di atas berdasarkan Rencana Pembangunan J angka Menengah Nasional (RPJ MN) 2010-2014, bahwa dalam rangka mendukung terwujudnya Indonesia yang sejahtera, demokrasi, dan berkeadilan maka kebijakan pembangunan di bidang hukum dengan strategi: peningkatan efektivitas peraturan perundang-undangan, peningkatan kinerja lembaga di bidang hukum, peningkatan penghormatan, pemajuan, dan penegakan HAM. ${ }^{29}$ Oleh karena itu agenda penegakan hukum pada RPJ MN 2010-2014 yaitu: masyarakat yang demokratis disertai tegaknya "rule of law", terwujudnya kepastian hukum yang memberikan rasa aman, adil, kepastian berusaha dan masuknya investor, peningkatan kualitas pembuatan undangundang, kelembagaan hukum dan sumber daya manusia (SDM) hukum, peningkatan peradilan bebas, transparan dan terbuka, perjanjian pemberantasan korupsi disertai perjanjian ekstradisi dengan negara lain, pembenahan berlanjut struktur, substansi dan budaya hukum, peningkatan "equality before the law", aturan hukum yang pasti merupakan tugas semua pihak, pemerintah, pengusaha dan apartur penegak hukum.

Perkembangan dan perubahan sosial yang demikian pesat sebagai akibat dari perkem-

Pencemaran Air, Jurnal Penelitian FHUI No. 1 Vol. 3 Tahun 2002, hlm. 65

27 Contoh dalam bidang pengelolaan lingkungan hidup, bahwa Politik hukum pengelolaan lingkungan dapat diartikan sebagai arah kebijakan hukum pengelolaan lingkungan yang dibuat oleh negara untuk mencapai tujuan tertentu dalam bidang lingkungan. M. Akib, "Politik Hukum Pengelolaan Lingkungan dan Refleksinya Dalam Produk Hukum Otonomi Daerah", Jurnal Media Hukum FH UMY Vol. 16 No. 3 Th 2011, hlm. 574

28 http:// www.bphn.go.id/ diunduh tgl. 11-10-2010.

29 Lampiran Perpres Nomor 5 Tahun 2010 tentang Rencana Pembangunan J angka Menengah Nasional (RPJ MN) Tahun 2010-2014. Bab VIII.II. 8.2. 
bangan tekhnologi dan industri, menghendaki hadirnya suatu tatanan hukum yang mampu mewujudkan tujuan-tujuan yang dikehendaki masyarakat. Oleh karena itu agar fungsi cita hukum dapat mengakomodasi semua dinamika masyarakat yang kompleks seperti Indonesia maka dalam penyusunan peraturan perundangundangan yang bersifat demokratis harus mempresentasikan peran hukum sebagai alat untuk mendinamisasikan masyarakat. ${ }^{30}$ Dalam konteks demikian, hukum merupakan suatu kebutuhan yang melekat pada kehidupan sosial. Hukum melayani anggota-anggota masyarakat dalam mengalokasikan kekuasaan, mendistribusikan sumber daya, melindungi kepentingan anggotaanggota ma-syarakat dan menjamin tercapainya tujuan yang telah ditetapkan dalam masyarakat. Dengan demikian cita hukum yang berisi patokan nilai harus mewarnai setiap produk peraturan perundang-undangan sehingga terwujud tatanan hukum yang demokratis. Tanpa cita hukum maka produk hukum yang dihasilkan akan kehilangan maknanya. Sehubungan dengan itu maka politik hukum yang diharapkan adalah politik hukum yang mampu mewujudkan cita hukum dan sekaligus dapat membahagiakan masyarakat Indonesia. Agar hukum dapat menjawab kepentingan masyarakatnya, maka hukum paling tidak dapat berfungsi: sebagai bagian dari sistem kontrol sosial,fungsi hukum sebagai alat penyelesai sengketa dan fungsi redistribusi (redistributive function) atau fungsi rekayasa sosial (social engineering function).

Hukum pada dasarnya untuk membahagiakan manusia. Sehubungan dengan itu reformasi hukum dalam rangka membangun Sistem

30 Bandingkan pendapat Romli Atmasasmita, yang menyatakan bahwa praktik kebijakan hukum pemegang kekuasaan telah memahami secara keliru atas konsep dan kebijakan hukum pembangunan khusus penggunaan kalimat "sarana" yang disamakan dengan "alat" (tools). Kekeliruan dalam politik hukum tersebut terlihat dengan disyahkannya beberapa undang-undang di era reformasi yang mencerminkan karakteristik hukum sebagai "alat" bukan "sarana pembaharuan masyarakat". Romli Atmasasmita, "Politik Hukum Pidana Dalam Pembangunan Nasional", Maj alah Hukum Nasional BPHN Depkumham No. 1 Tahun 2011, hlm. 167. Lihat juga Teguh Samudra, "Politik Hukum Pidana dan Politik Pemidanaan", Majalah Hukum Nasional BPHN Depkumham No. 1 Tahun 2011, hlm. 65. hukum nasional harus berorientasi kemanusiaan sesuai Pancasila. ${ }^{31}$ Ini berarti pembangunan tentang substansi hukum, pembangunan tentang struktur hukum, dan pembangunan tentang budaya hukum harus memperhatikan HAM dan KAM bangsa Indonesia yang menurut Ketetapan MPR Nomor II/MPR/ 1978 tentang Pedoman Penghayatan dan Pengamalan Pancasila (P4) meliputi: mengakui persamaan derajat, persamaan hak dan persamaan kewajiban antara sesama manusia, Saling mencintai sesama manusia, Mengembangkan sikap tenggang rasa, Tidak semena-mena terhadap orang lain, Menjunjung tinggi nilai kemanusiaan, Gemar melakukan kegiatan kemanusiaan, Berani membela kebenaran dan keadilan, Bangsa Indonesia merasa dirinya sebagai bagian dari seluruh umat manusia, karena itu dikembangkan sikap hormat menghormati dan bekerjasama dengan bangsa lain.

Selain itu, apabila bangsa Indonesia hendak membangun sistem hukum yang berkarakteristik Indonesia (Sistem Hukum Pancasila), maka bangsa Indonesia dituntut untuk mengartikan hukum tidak hanya terpaku dengan kerja logika-deduktif semata yang masuk ranah legalistik-dogmatik dan empirik-positivistik, melainkan juga hukum harus dibangun secara humanis-partisipatoris, bermoral, hukum bukan untuk hukum melainkan untuk manusia dan masyarakat (logika-induktif). ${ }^{32}$ Agar cita hukum

31 Bandingkan dengan pendapat Notonengoro mengenai posisi sila pertama dibandingkan dengan sila-sila yang lain. Lihat dalam Astin Riyanto, "Pancasila Dasar Negara Indonesia", J urnal Hukum dan Pembangunan FHUI Tahun Ke 37 No. 3 2007, hlm. 464.

32 Bandingkan pendapat Oding Djunaedi, bahwa diterimanya Pancasila sebagai sumber hukum dapat sejalan dengan pemikiran dan teori hukum antara lain: (1) Teori hukum yang dikemukakan Hans Kelsen dengan Stufenbau desrecht "hukum itu bersifat hirarkhis" bertingkat. Tingkatan hukum yang paling tinggi derajatnya adalah Ground Norm yang tidak Iain adalah dasar-dasar sosial dari pada hukum untuk bangsa Indonesia, tidak lain adalah Pancasila; (2) Mazhab sejarah, yang dipelopori oleh Carl von Savigny menyatakan bahwa "hukum itu tidak dibuat, akan tetapi tumbuh dan berkembang bersama-sama dengan masyarakat (volkgeist).; (3) Aliran Utility, dari J eremy Bentham, konsepnya "hukum itu harus bermanfaat bagi masyarakat, guna mencapai hidup bahagia"; (4) Aliran Sociological Yurisprudence, dari Eugen Ehrlich, yang konsepnya "hukum yang dibuat harus sesuai dengan hukum yang hidup di dalam masyarakat" (Iiving law). Oding Djunaedi, "Pancasila Sebagai Paradigma Perkembangan Hukum, Jurnal IImiah Fakul- 
Pancasila dapat terwujud dalam setiap produk perundang-undangan Indonesia, maka proses pembentukannya tidak hanya melalui pendekatan yuridis, melainkan juga harus memperhatikan pendekatan sosiologis dan politis bahkan filosofis. ${ }^{33}$

Pentingnya perubahan cara pandang terhadap hukum tersebut, mengingat belenggu pemikiran normative positivis ternyata menyebabkan keterpurukan dalam hukum, sehingga untuk keluar dari keterpurukan hukum tersebut, harus membebaskan diri dari belenggu positivis. Hal ini karena pemikiran positivis-legalistik yang hanya berbasis pada peraturan tertulis (rule bound) semata tidak akan pernah mampu dan dapat menangkap hakikat kebenaran. Sehingga perlu ada pemikiran yang responsif terhadap rasa keadilan dalam masyarakat untuk mencari dan mengurai benang keadilan dan kebenaran. Pemikiran ini dilandasi bahwa bangunan hukum dibangun oleh hubungan antar manusia sebagai hubungan sosial antar individu dengan keseluruhan variasi dan kompleksitasnya yang cenderung sifatnya asimetris. Dalam artian hukum tunduk pada kekuatan sentripetal yang menciptakan keteraturan, sekaligus tunduk pada kekuatan sentrifugal yang menciptakan ketidakteraturan (disorder), chaos maupun konflik. Sehingga hukum tidak dapat dipandang sebagai sesuatu yang kaku (formallegalistik-positivis) tetapi harus lentur memperhatikan fakta dan realitas sosial sebagaimana pendapat Charles Stamford yang dikutip oleh Ahmad Ali. ${ }^{34}$

tas Hukum Universitas Swadaya Gunung Jati Cirebon, Edisi:01/J uni/2005, hlm. 7

33 Bandingkan pendapat Artidjo Alkostar, bahwa politik pemidanaan dalam RUU KUHP dituntut untuk menyesuaikan dengan dinamika hukum yang bergerak secara sentripetal ke arah nilai-nilai kebenaran (logis), keadilan (etis), harmoni sosial (estetis) bersamaan secara sentrifugal ke arah perkembangan lingkungan sosial, politik, dan budaya. Secara sentrifugal hukum Indonesia sejatinya mampu mengadopsi dan menyerap konvensikonvensi internasional dan secara bersamaan juga menginternalisasikan nilai-nilai kearifan lokal, termasuk diantaranya islah, restorative justice dan mediasi daIam perkara pidana. Artidjo Alkostar, "Politik Pemidanaan di Dalam RUU KUHP", Majalah Hukum Nasional BPHN Depkumham No. 1 Tahun 2011.

34 Ahmad Ali, 2002. Keterpurukan Hukum di Indonesia Penyebab dan Solusinya, Jakarta: Ghalia Indonesia, hlm. 48. Bandingkan pendapat Daniel S. Lav, yang menyata-
Perwujudan cara berpikir doktrinal tentang hukum, tergambar adanya pemahaman bahwa undang-undang dipandang sebagai sarana yang paling efektif untuk mengawal kebijakan penguasa negara (law effectively legitimates policy). Di samping itu peraturan perundang-undangan merupakan cara utama penciptaan hukum nasional dikarenakan oleh sistem hukum Indonesia berorientasi pada sistem hukum Hindia Belanda yang merupakan sistem hukum kontinental yang mengutamakan bentuk sistem hukum tertulis, politik pembangunan hukum nasional mengutamakan penggunaan peraturan perundang-undangan sebagai instrumen utama dibandingkan hukum yurisprudensi dan hukum kebiasaan. ${ }^{35}$

Menentukan politik hukum juga harus memperhatikan fungsi hukum yang sangat berkaitan dengan struktur masyarakatnya. Dalam hal ini bagi masyarakat sederhana yaitu masyarakat yang masih kecil jumlahnya dan pola hubungan antar para anggota masih terjalin sangat erat berdasarkan asas kekerabatan sehingga penyelenggaraan keadilan relatif mudah maka fungsi hukum hanya sebatas mengatur standar berperilaku masyarakat, yang oleh Hart dise-but primary rules of obligation. Sebaliknya bagi masyarakat yang sudah kompleks dibutuhkan tatanan hukum yang memiliki kewajiban sekundair (secondary rules of obligation) meliputi peraturan-peraruran yang berisi pengakuan norma tertentu (rules of recognition), peraturan-peraturan yang menggarap perubahan-perubahan (rules of change), dan peraturan tentang penyelesaian sengketa (rules of adjudication) sehingga hukum berfungsi selain sebagai sosial kontrol (social control) juga berfungsi sebagai rekayasa sosial (social engineering). ${ }^{36}$

kan bahwa hukum tidak pernah dapat berdiri sendiri. Hukum harus dilihat dengan mempertimbangkan konteks politik yang melingkupinya. Lihat dalam Indriastuti Dyah Saptaningrum, "J ejak Neoliberalisme Dalam Perkembangan Hukum Indonesia", J urnal Hukum J entera, Edisi Khusus 2008. hlm. 72.

35 Bagir Manan, 1994. Fungsi dan Materi Peraturan Perundang-Undangan, Makalah Penataran Dosen PLKH BKSPTN Bidang Hukum Se-Wilayah Barat FH Unila Bandar Lampung, hlm. 10.

36 Bandingkan pendapat Romli Atmasasmita, yang menyatakan bahwa model hukum pembangunan (hukum sebagai sarana pembangunan, pen) justru dalam praktek 
Berdasarkan uraian di atas, agar politik hukum penggantian hukum-hukum kolonial dengan hukum nasional mampu memenuhi kepentingan hukum masyarakat Indonesia, maka bentuk politik hukumnya adalah sebagai berikut: hukum kolonial yang sukar diganti seperti bidang hukum yang erat hubungannya dengan kehidupan kemasyarakatan, budaya dan spiritual masyarakat seperti bidang-bidang hukum pidana, kekeluargaan dan waris, maka politik hukumnya berbentuk pembinaan terhadap hukum kolonial yaitu tetap memberlakukan hukum produk kolonial sepanjang tidak bertentangan dengan kondisi Indonesia. Hal ini sesuai dengan ketentuan Pasal II Aturan Peralihan UUD 1945, hukum kolonial yang bersifat hukum "netral" seperti hukum perikatan dan hukum dalam bidang perdagangan maka politik hukumnya berbentuk pembaharuan yaitu melakukan penyesuaian hukum kolonial terhadap kondisi sosial, politik dan budaya bangsa Indonesia atau berbentuk penciptaan hukum yaitu merubah secara total substansi produk hukum kolonial dengan hukum nasional.

\section{Penutup}

Simpulan.

Berdasarkan pembahasan di atas, dapat ditarik simpulan bahwa faktor penyebab adanya problematik penggantian hukum-hukum kolonial dengan hukum nasional antara lain: heterogenitas bangsa Indonesia, dianutnya prinsip unifikasi dan kodifikasi dalam sistem hukum nasional, adanya perbedaan pandangan terhadap Hak Asasi Manusia.

Politik hukum dalam mengatasi problematik tersebut yaitu melakukan pembinaan terhadap hukum kolonial yang sukar diganti seper-

pembentukan hukum dan penegakan hukum masih sering mengalami hambatan-hambatan yaitu kebiasaan kurang terpuj i selama 50 tahun Indonesia merdeka yaitu pengambilan kebijakan sering memanfaatkan celah untuk menggunakan hukum sekedar sebagai alat (mekanis) dengan tujuan memperkuat dan mendahulukan kepentingan kekuasaan daripada kepentingan dan manfaat bagi masyarakat seluas-luasnya, seperti perampasan hak masyarakat adat atas tanah untuk tujuan pembangunan gedung pemerintah dan jalan raya. Romli Atmasasmita, "Tiga Paradigma Hukum Dalam Pembangunan Nasional", Majalah Hukum Nasional BPHN Depkumham No. 2 Tahun 2011, hlm. 199. ti bidang hukum yang erat hubungannya dengan kehidupan kemasyarakatan, budaya dan spiritual masyarakat seperti bidang-bidang hukum pidana, kekeluargaan dan waris. Sedangkan bidang hukum "netral" seperti hukum perikatan dan hukum dalam bidang perdagangan dilakukan pergantian melalui dimensi pembaharuan atau penciptaan hukum.

\section{Saran}

Disarankan adanya kebijakan negara yang mewajibkan semua hukum positif yang masih berbahasa Belanda (dimensi pembinaan) segera diganti dengan bahasa Indonesia melalui proses legislasi.

\section{Daftar Pustaka}

Akib, M. "Politik Hukum Pengelolaan Lingkungan dan Refleksinya Dalam Produk Hukum Otonomi Daerah". J urnal Media Hukum FH UMY Vol. 16 No. 3 Th 2011;

Ali, Ahmad. 2002. Keterpurukan Hukum di Indonesia Pe-nyebab dan Solusinya, Jakarta: Ghalia Indonesia;

Alkostar, Artidjo. "Politik Pemidanaan di dalam RUU KUHP". Majalah Hukum Nasional No. 1 Tahun 2011. BPHN Depkumham;

Atmasasmita, Romli. "Politik Hukum Pidana Dalam Pembangunan Nasional". Majalah Hukum Nasional No. 1 Tahun 2011. BPHN Depkumham;

---.--. "Tiga Paradigma Hukum Dalam Pembangunan Nasional". Majalah Hukum Nasional No. 2 Tahun 2011. BPHN Depkumham;

Dadan Wildan. "Nasionalisme dan Jati Diri Bangsa di Era Globalisasi", J urnal Sekretariat Negara RI Negarawan, No. 08 Mei 2008;

Djunaedi, Oding. "Pancasila Sebagai Paradigma Perkembangan Hukum". Jurnal IImiah Edisi: 01/J uni/2005. FH Unswagati Cirebon;

Fakrulloh, Zudan Arif. "Model Hukum Yang Humanis Partisipa-toris: Ide Dasar dan Teorisasinya dengan Latar Sosial Indonesia". J urnal IImiah Hukum Legality Vol. 9. No. 2. September 2001-J anuari 2002. F UMM Malang, ;

Hasan, Ahmadi. "Adat Badamai Sebagai Penyelesaian Sengketa Dalam Sistem Hukum Nasional". J urnal Konstitusi PKK Vol. I No 
1, Nopember 2008. Fakultas Syariah IAIN Antasari;

Hikmah, Mutiara. "Aspek Penegakan Hukum Pada Pencemaran Air". Jurnal Penelitian FHUI No. 1 Vol. 3 Tahun 2002;

Kusumaatmadja, Mochtar. 1986. Pembinaan Hukum dalam Rangka Pembangunan Nasional. Bandung: Binacipta;

Kusumohamidjojo, Budiono. "Politik Hukum dan Pembangunan Hukum Nasional Dalam PJ PT II". Pro J ustitia Majalah Hukum 1993. Unpar Bandung;

Lumbun, Gayus T. "Politik Hukum Bidang Peradilan di Indonesia". Majalah Hukum Nasional No. 1 Tahun 2008. BPHN Depkumham Rl;

-.----. "Budaya Hukum Mempengaruhi Pelestarian Fungsi Lingkungan". Jurnal IImiah IImu Hukum "Era Hukum" No. 1 Tahun 11 September 2003;

Ma'ruf, Umar. "Politik Hukum Hak Menguasai oleh Negara Terhadap Tanah". J urnal IImu Hukum Vol XVI No. 3 September 2006. FH Unissula;

Mahmutarom. "Pembangunan Hukum Nasional Dalam Konteks Global". Majalah MasalahMasalah Hukum Vol 35 No 1 J anuari-Maret 2006. FH UNDIP;

Manan, Bagir. 1994. Fungsi dan Materi Peraturan Per-undang-Undangan. Makalah Penataran Dosen PLKH BKS-PTN Bidang Hukum Se-Wilayah Barat FH Unila Bandar Lampung;

Mansyur, M. Ali. "Pancasi-la Sebagai Dasar Pengembangan Ilmu Hukum Indonesia". J urnal Hukum Vol. XV No.1 J uni 2005. FH Unissula;

Mudzakkir. "Kebijakan Kodifikasi (Total) Hukum Pidana Melalui RUU KUHP dan AntisipasiTerhadap Problem Perumusan Hukum Pidana dan Penegakan Hukum Pidana di Masa Datang". Majalah Hukum Nasional No. 1 Tahun 2011. BPHN Depkumham;

Mulyanto. "Potret Nilai Universal Versus Nilai Partikular Hak Asasi Manusia (HAM) Dalam Bingkai Konstitusi di Indonesia". Jurnal Konstitusi Vol. I, No. 1, Agustus 2008 P3KHAM LPPM UNS;

Rahardjo, Satjipto. 2007. Biarkan Hukum Mengalir: Catatan Kritis tentang Pergulatan
Manusia dan Hukum. Jakarta: Penerbit Buku Kompas;

Riyanto, Astim. "Sistem Hukum Negara-Negara Asia Tenggara". Jurnal Hukum \& Pembangunan Tahun-37 No. 2 April-J uni 2007;

-.-.-.. "Pancasila Dasar Negara Indonesia". Jurnal Hukum dan Pembangunan Tahun Ke 37 No. 3 2007;

Rokhmad, Abu. "HAM dan Demokrasi di Era Globalisasi Menuju Promosi dan Perlindungan HAM Generasi Kedua". Jurnal Hukum Vol. XV. No. 3 Desember 2005. FH Unissula;

Said, Noor Aziz. "Aspek-Aspek Sosiologik Sistem Hukum Nasional (Tinjauan Kritis Terhadap Kasus Bank Century)". Jurnal Dinamika Hukum Vol. 10 No. 3 September 2010. FH UNSOED Purwokerto;

Samudra, Teguh. "Politik Hukum Pidana dan Politik Pemidanaan". Majalah Hukum Nasional No. 1 Tahun 2011. BPHN Depkumham;

Saptaningrum, Indriastuti Dyah. "J ejak Neoliberalisme Dalam Per-kembangan Hukum Indonesia". Jurnal Hukum J entera, Edisi Khusus 2008. hlm. 72.

Shidarta. "Penalaran Hukum Dalam Sudut Pandang Keluarga Sistem Hukum dan Penstudi Hukum". J urnal IImiah IImu Hukum "Era Hukum" No. 1 Tahun 11 September 2003;

Soemarsono, Maleha. "Negara Hukum Indonesia Ditinjau Dari Sudut Teori Tujuan Negara". Jurnal Hukum \& Pembangunan Tahun-37 No. 2 April-J uni 2007;

SS, Soehardjo. 1993. Filsafat Hukum, Bahan Kuliah Program Magister Hukum Undip Semarang;

Sukriono, Didik. "Politik Hukum Pemerintahan Desa di Indonesia". J urnal Konstitusi Vol. I, No. 1, September 2008. PKK Universitas Kanjuruhan Malang;

Sulistiyono, Tri. "Pluralisme Hukum; Menggapai Hu-kum Adat Gaya Baru yang Berperspektif Keadilan Gen-der". J urnal Konstitusi Vol. I, No. 1. Nopember 2008. PKK Universitas Negeri Sema-rang, ;

Sutrisno, Endang. "Mengukuhkan Paradigma Hukum di Era Orde Reformasi". Jurnal IImiah Edisi: 01/J uni/2005. FH Unswagati Cirebon; 